\title{
Immunohistochemistry for the detection of neural and inflammatory cells in equine brain tissue
}

Gretchen H Delcambre, Junjie Liu, Jenna M Herrington, Kelsey Vallario, Maureen T Long

Phenotypic characterization of cellular responses in equine infectious encephalitides has had limited description of both peripheral and resident cell populations in central nervous system (CNS) tissues due to limited species-specific reagents that react with formalinfixed, paraffin embedded tissue (FFPE). This study identified a cassette of antibodies for investigating the immunopathology of infectious CNS diseases in horses. Multiple commercially available staining reagents and antibodies derived from antigens of various species for manual immunohistochemistry (IHC) were screened. Several techniques and reagents for heat-induced antigen retrieval, non-specific protein blocking, endogenous peroxidase blocking, and visualization-detection systems were tested during $\mathrm{IHC}$ protocol development. Boiling of slides in a low pH, citrate-based buffer solution in a double-boiler system was most consistent for epitope retrieval. Pressure-cooking, microwaving, high $\mathrm{pH}$ buffers, and proteinase $\mathrm{K}$ solutions often resulted in tissue disruption or no reactivity. Optimal blocking reagents and concentrations of each working antibody were determined. Ultimately, a cassette of monoclonal (mAb) and polyclonal antibodies ( $\mathrm{pAb}$ ) were identified for $\mathrm{CD}^{+}$(pAb A0452, Dako) T-lymphocytes, CD79acy+ B-lymphocytes (mAb HM57, Dako), macrophages (mAb MAC387, Leica), NF-H $\mathrm{H}^{+}$neurons (mAb NAP4, EnCor Biotechnology), microglia/macrophage (pAb Iba-1, Wako), and GFAP ${ }^{+}$astrocytes (mAb 5C10, EnCor Biotechnology). In paraffin embedded tissues, mAbs and pAbs derived from human and swine antigens were very successful at binding equine tissue targets. Individual, optimized protocols are provided for each positively reactive antibody for analyzing equine neuroinflammatory disease histopathology. 
1 Immunohistochemistry for the Detection of Neural and Inflammatory Cells in Equine

\section{Brain Tissue}

3

4 Gretchen H. Delcambre ${ }^{1}$, Junjie Liu², Jenna M. Herrington ${ }^{2}$, Kelsey Vallario², Maureen T.

5 Long $^{2}$

6

$7{ }^{1}$ Department of Biomedical Sciences, College of Veterinary Medicine and Biomedical

8 Sciences, Colorado State University, Fort Collins, CO, USA

9

102 Department of Infectious Diseases and Pathology, College of Veterinary Medicine,

11 University of Florida, Gainesville, FL, USA

12

13 Corresponding Author:

14 Gretchen Delcambre ${ }^{1}$

151617 Campus Delivery, Colorado State University, Ft. Collins, Co 80523-1617, USA

16 Email address: GH.Delcambre@colostate.edu 


\section{Abbreviations}

19 CNS Central nervous system

20 EDTA Ethylenediaminetetraacetic acid

21 FFPE Formalin-fixed, paraffin embedded

22 GFAP Glial fibrillary acid protein

$23 \mathrm{H}_{2} \mathrm{O}_{2} \quad$ Hydrogen peroxide

24 HIER Heat induced epitope retrieval

25 HRP Horseradish peroxidase

26 IgG Immunoglobulin

27 IHC Immunohistochemistry

$28 \mathrm{mAb} \quad$ Monoclonal antibody

29 MHC Major histocompatibility complex

30 NF-H Neurofilament - heavy chain

$31 \mathrm{pAb} \quad$ Polyclonal antibody

32 PBS Phosphate buffered saline

33 WNV West Nile virus 


\section{Abstract}

39 Phenotypic characterization of cellular responses in equine infectious encephalitides has had

40 limited description of both peripheral and resident cell populations in central nervous system

41 (CNS) tissues due to limited species-specific reagents that react with formalin-fixed, paraffin

42 embedded tissue. This study identified a set of antibodies for investigating the

43 immunopathology of infectious CNS diseases in horses. Multiple commercially available

44 staining reagents and antibodies derived from antigens of various species for manual

45 immunohistochemistry (IHC) were screened. Several techniques and reagents for heat-induced

46 antigen retrieval, non-specific protein blocking, endogenous peroxidase blocking, and

47 visualization-detection systems were tested during IHC protocol development. Boiling of slides

48 in a low $\mathrm{pH}$, citrate-based buffer solution in a double-boiler system was most consistent for

49 epitope retrieval. Pressure-cooking, microwaving, high $\mathrm{pH}$ buffers, and proteinase $\mathrm{K}$ solutions

50 often resulted in tissue disruption or no reactivity. Optimal blocking reagents and concentrations

51 of each working antibody were determined. Ultimately, a set of monoclonal (mAb) and

52 polyclonal antibodies (pAb) were identified for $\mathrm{CD}^{+}$(pAb A0452, Dako) T-lymphocytes,

$53 \mathrm{CD} 79 \mathrm{acy}^{+}$B-lymphocytes (mAb HM57, Dako), macrophages (mAb MAC387, Leica), NF-H ${ }^{+}$

54 neurons (mAb NAP4, EnCor Biotechnology), microglia/macrophage (pAb Iba-1, Wako), and

$55 \mathrm{GFAP}^{+}$astrocytes (mAb 5C10, EnCor Biotechnology). In paraffin embedded tissues, mAbs and

56 pAbs derived from human and swine antigens were very successful at binding equine tissue

57 targets. Individual, optimized protocols are provided for each positively reactive antibody for 58 analyzing equine neuroinflammatory

disease

histopathology. 


\section{Introduction}

60 Comparative pathology of many diseases that affect multiple species is hindered by the lack of

61 species-specific reagents. Although many antibodies that react with cellular antigens and

62 inflammatory molecules are available, there still are gaps in how these work in formalin-fixed

63 paraffin embedded (FFPE) tissues. This limits our ability to generate new knowledge about

64 disease processes that can benefit human and animal health as a whole. Horses develop many of

65 the same or similar central nervous system (CNS) infections as humans (Ritchey et al., 2006,

66 Bourgeois et al., 2011, Rushton et al., 2013, and Yu et al., 2015). Cell marker panels are often

67 composed of both equine and non-equine specific antibodies, of which most are used in flow

68 cytometry. Since manufacturers may not have supporting technical documentation on whether

69 their products will cross-react with equine antigens (Beckstead, 1994 and Ramos-Vara, 2005),

70 development of antibody panels to accomplish in situ disease characterization in formalin-fixed

71 tissue is a formidable task because cross-linking of antigens often renders epitopes non-reactive.

72 Additional investigative steps are required to determine if antigens can be retrieved and what

73 retrieval method works best. Because of this and other hurdles, there is limited information on

74 what antibodies react with FFPE tissue.

75 The goal of this study was to identify a panel of cell markers for studying cellular pathogenesis

76 in equine infectious brain diseases. In particular, protocols for phenotyping reactive glia,

77 neurons, and infiltrating peripheral blood mononuclear and polymorphonuclear cells in the

78 equine brain were developed. Commercially available antibodies for $\mathrm{CD}^{+} \mathrm{T}$-lymphocytes,

$79 \mathrm{CD}^{+}$and $\mathrm{CD}^{+} \mathrm{T}$ cell subpopulations, B lymphocytes, macrophages, microglia, astrocytes, and

80 neurons were investigated for reactivity in normal and diseased FFPE tissue. Optimization of 
81 manual immunohistochemistry (IHC) protocols was performed using various IHC staining

82 reagents and methods.

\section{Materials and methods}

84 Tissue samples

85 Immunohistochemistry protocols were developed on diseased and normal horse tissues.

86 Diseased horses consisted of clinically affected West Nile virus (WNV), both naturally and 87 experimentally infected, and Sarcocystis neurona infections (Beckstead, 1994, Gutierrez et al., 88 1999, Porter et al., 2003, and Seino et al., 2007). Neurologically, normal horses were obtained 89 by owner surrender for humane euthanasia due to loss of use. Brain, spinal cord, lymph node, 90 spleen, thymus, and liver were collected and archived from these animals under University of 91 Florida (Gainesville, FL) Institutional Animal Care and Use Committee protocols \#F077, \#F093, 92 \#D163, and \#4109. Tissues were fixed in 10\% neutral buffered formalin and processed into 93 paraffin-embedded blocks approximately one-week after fixation. Initial evaluation of antibody 94 binding was tested on non-infected equine lymph node and spleen for lymphocytic targets, liver 95 and thymus for tissue macrophage targets, and brain for microglia, astrocytes, and neurons.

96 Tissue processing

97 The invariable IHC procedures for all protocols included sectioning FFPE tissues at $5 \mu \mathrm{m}$ and 98 placing them on positively charged glass slides. The slides were soaked in xylene (Fischer 99 Scientific, Pittsburg, PA, USA) three times for $5 \mathrm{~min}$ to remove paraffin. These sections were 100 then rehydrated through a gradient of ethanol (Fischer Scientific) for 5 min in each 101 concentration, $100 \%, 100 \%, 95 \%$, and $70 \%$ ethanol, followed by de-ionized water. In order to 102 reduce the volume of the reagents tested and liquid loss, tissues were encircled with a 103 hydrophobic barrier pen (ImmEdge ${ }^{\mathrm{TM}}$ Pen, Ted Pella Inc., Redding, CA, USA). 


\section{Antigen Unmasking}

105 Three methods of heating slides for investigating heat induced epitope retrieval (HIER)

106 effectiveness included using a pressure cooker, microwave, and a double boiler. Pressure

107 cooking was performed at $125^{\circ} \mathrm{C}$ for $30 \mathrm{~s}$ followed by $90^{\circ} \mathrm{C}$ for $10 \mathrm{~s}$ (Matyjaszek et al., 2009 and

108 Grosche et al., 2012), or microwaving was performed for 10 min (DAKO, 2009) using a

109 commercial countertop GE 1000W oven. For double boiling, two tissue-slides were floated

110 back-to-back in $25 \mathrm{ml}$ of retrieval solution in a $50 \mathrm{ml}$ plastic conical tube. Conical tubes were

111 then placed in pre-warmed water of a $250 \mathrm{ml}$ glass beaker on a hotplate. Water temperature was

112 maintained at $90^{\circ} \mathrm{C}$. After approximately 5 min of warming the retrieval solution, HIER was

113 timed for $10 \mathrm{~min}$. Conical tubes were then removed from the double boiler and allowed to cool

114 for $15 \mathrm{~min}$ at $27^{\circ} \mathrm{C}$. Tissues were rinsed in deionized water three times for $2 \mathrm{~min}$.

115 Heat induced epitope retrieval buffers were tested primarily using the double boiler system.

116 Regents included two commercial citrate buffers, Epitope Retrieval Solution pH 6 (Novacastra,

117 Leica, Newcastle Upon Tyne, UK) and Target Retrieval Solution pH 6 (Dako, Glostrup,

118 Denmark), and an ethylenediaminetetraacetic acid (EDTA) solution buffered at pH 9 (10 mM

119 Tris Base, $1 \mathrm{mM}$ EDTA solution, $0.05 \%$ Tween 20, and $\mathrm{NaOH}$ to titrate to $\mathrm{pH} 9$ ). A $1 \times$

120 concentration of each solution was freshly made by diluting stock solutions with deionized

121 water. For proteolytic epitope retrieval, tissues were treated with $200 \mathrm{ug} / \mathrm{ml}$ proteinase K

122 solution [Tris HCL $100 \mathrm{mM} \mathrm{pH} \mathrm{8.2,} \mathrm{Tween} \mathrm{20,} \mathrm{and} \mathrm{Proteinase} \mathrm{K} \mathrm{(Ambion,} \mathrm{Foster} \mathrm{City,} \mathrm{CA,}$

$123 \mathrm{USA})]$ for $10 \mathrm{~min}$ at $37^{\circ} \mathrm{C}$.

\section{Endogenous Peroxidase Blocking}

125 Peroxidase neutralizing solutions that were tested included two prepared solutions of hydrogen 126 peroxide $\left(\mathrm{H}_{2} \mathrm{O}_{2}\right), 3 \%$ and $0.3 \% \mathrm{H}_{2} \mathrm{O}_{2}$, and a ready-to-use commercial reagent, Peroxidase Block 
127 (Novolink ${ }^{\mathrm{TM}}$ Polymer Detection System, Leica). Solutions containing 3\% and 0.3\% $\mathrm{H}_{2} \mathrm{O}_{2}$ were

128 made fresh for each staining attempt by diluting $30 \% \mathrm{H}_{2} \mathrm{O}_{2}$ (Fischer Scientific) in $1 \times$ phosphate

129 buffered saline $(\mathrm{PBS})(10 \times \mathrm{PBS}$, Fischer Scientific). Tissues were immersed in peroxidase

130 blocking solution for 5 min followed by two, 5 min rinses in PBS.

131 Non-specific Protein Blocking

132 Non-specific blocking techniques included four commercial reagents and one lab prepared

133 solution. Commercial reagents included 10\% Normal Goat Serum (Invitrogen, Frederick, MD,

134 USA), Protein Block (Novolink ${ }^{\mathrm{TM}}$ Polymer Detection Systems, Leica), Novocastra ${ }^{\mathrm{TM}}$ IHC/ISH

135 Super Blocking Solution (Leica), and Novocastra ${ }^{\mathrm{TM}}$ Liquid Serum, Normal Goat Serum

136 Blocking Reagent (Leica). Additionally, a 5\% goat serum solution was prepared by diluting

137 Immunopure ${ }^{\circledR}$ Goat Serum (ThermoFischer Scientific, Waltham, MA, USA) in $1 \times$ PBS.

138 Protein blocking reagents were applied for 20 min with the exception of Novolink ${ }^{\mathrm{TM}}$ Protein

139 block for only 5 min. Blocking reagents were removed without rinsing before adding primary

140 antibody.

141 Primary Antibodies

142 Primary antibodies tested targeted cell populations of astrocytes, microglia, neurons, $\mathrm{T}$

143 lymphocytes, B lymphocytes, and macrophages (Table 1). All primary antibodies were diluted

144 in one of two commercial diluents [IHC Diluent (Novacastra, Leica); Dako Antibody Diluent

145 (Dako)]. Two-fold serial dilutions of each antibody were tested to determine an optimal staining

146 range. If the signal was weak to absent or background staining was present, additional dilution

147 tests were performed until optimal staining was achieved. Antibodies were applied in a $37^{\circ} \mathrm{C}$,

148 humidified incubator for $60-120 \mathrm{~min}$ or overnight $(\sim 16 \mathrm{hrs})$ at $4^{\circ} \mathrm{C}$ in a humidified, covered dish. 
149 After primary antibody incubation, slides were washed three times for 5 min each in $1 \times$ PBS

150 before secondary antibody application.

151 Negative controls for each primary antibody consisted of either an isotype-matched negative

152 primary control (MCA928, AbD Serotec, Kidlington, UK) for monoclonal antibodies or rabbit 153 serum for polyclonal antibodies.

\section{Detection Systems}

155 Three commercial, horseradish peroxidase (HRP)-linked conjugate detection kits were utilized 156 by following manufacturer's instructions. These kits included the Vectastain ${ }^{\circledR}$ ABC Kit - Mouse

157 IgG (Vector Laboratories, Burlingame, CA, USA), the Vectastain ${ }^{\circledR}$ ABC Kit - Rabbit IgG, and 158 the Novolink ${ }^{\mathrm{TM}}$ Polymer Detection System (Leica).

159 Lastly, a substrate-chromogen (Vector NovaRED Peroxidase Substrate, Vector Laboratories)

160 was applied for $10 \mathrm{~min}$, rinsed with de-ionized water for $5 \mathrm{~min}$, counterstained with Lab

161 Vision ${ }^{\mathrm{TM}}$ Mayer's Hematoxylin (ThermoFisher Scientific) for $1 \mathrm{~min}$, and rinsed in running tap

162 water for $2 \mathrm{~min}$. All sections were then dehydrated through an increasing gradient of ethanol,

$16350 \%, 70 \%, 95 \%$, and $100 \%$, for $2 \mathrm{~min}$ each. Slides were cleared in xylene three times for $3 \mathrm{~min}$ 164 each before coverslipping with Permount ${ }^{\mathrm{TM}}$ mounting medium (Fischer Scientific).

\section{Results}

166 Antigen Unmasking

167 Of the reagents tested, low $\mathrm{pH}$ citrate based solutions resulted in superior staining (Table 2).

168 Target Retrieval Solution pH 6 by Dako was sufficient for most antibodies; however, use of 169 Epitope Retrieval Solution pH 6 by Leica resulted in positive staining when the Dako product 
170 failed to produce staining with the $\mathrm{CD} 79 \alpha \mathrm{y}^{+}$antibody. Proteinase $\mathrm{K}$ solution was tested with

171 macrophage antibodies and resulted in increased staining intensity of $\mathrm{MAC}_{387^{+}}$antibody.

172 Various issues were encountered with the method of applying heat. Utilizing, one antibody,

$173 \mathrm{CD} \mathrm{C} \alpha^{+}$, only the double boiling method resulted in consistent positive staining of lymph

174 nodes. Pressure cooking and microwaving resulted in limited to no staining or uneven staining,

175 respectively. In addition, tissue disruption was minimal with the double boiling method. One

176 antibody, Iba- $1^{+}$, did not require heat retrieval and any HIER resulted in non-specific background 177 staining.

178 Endogenous Peroxidase Blocking

179 In FFPE tissues, 3\% $\mathrm{H}_{2} \mathrm{O}_{2}$ solution was reliable for reducing background staining without

180 disruption of the tissue. There was no difference between commercial and lab diluted reagents.

181 Non-specific Protein Blocking

182 Multiple combinations of IHC antibody diluents and non-specific protein blocking reagents were

183 tested. No difference in staining intensity was noted between of either diluent used. Among

184 protein blocking solutions, 10\% Normal Goat Serum, Protein Block from the Novolink ${ }^{\mathrm{TM}}$

185 Polymer Detection System, and 5\% Immunopure ${ }^{\circledR}$ Goat Serum in PBS solution were all equal in 186 blocking non-specific staining.

187 Specificity and Sensitivity of Monoclonal and Polyclonal Antibodies

188 Several antibodies were tested for lymphocyte specific CD antigens including $\mathrm{CD}^{+}, \mathrm{CD}^{+}$, $189 \mathrm{CD}^{+}, \mathrm{CD}^{+}, \mathrm{CD} 20^{+}, \mathrm{CD} 21^{+}$, and $\mathrm{CD} 79{\alpha \mathrm{y}^{+}}^{+}$(Table 1). Of the two $\mathrm{CD}^{+}$, pan-T cell markers 190 examined, rabbit anti-human polyclonal antibody (A0452, Dako) appropriately stained lymph 191 node cortex (Fig. 1A), periarterial lymphatic sheaths of spleen, and perivascular cuffs in WNV 
192 infected brain (Fig. 1B). Four $\mathrm{CD}^{+}$T-helper cell antibodies were tested. Only mouse,

193 monoclonal anti-equine antibody (HB61A, VMRD, Pullman, WA, USA) at 1:25 dilution

194 positively stained lymph node cortex; however, background staining was high when applied to

195 brain tissues. Two $\mathrm{CD}^{+}$cytotoxic $\mathrm{T}$ cell markers were investigated, but neither marker had

196 reactivity in FFPE tissue.

197 Antibodies against $\mathrm{CD}^{+}, \mathrm{CD} 20^{+}, \mathrm{CD} 21^{+}, \mathrm{CD} 79 \alpha \mathrm{y}^{+}$, and $\mathrm{IgG}(\mathrm{H}+\mathrm{L})($ Table 1$)$ were tested for

198 identification of $\mathrm{B}$ cell populations. A putative lymphocyte marker, CD5 ${ }^{+}$(B29A, VMRD),

199 reportedly selects for B cells in equine tissues. Although this antibody intensely stained the

200 germinal centers of FFPE lymph nodes, cortical staining was also noted. Because of this, CD5 ${ }^{+}$

201 (B29A) was unreliable for distinction between B cell and T cell populations. Additionally in

202 brain tissue, this antibody resulted in non-specific background staining, which could not be

203 resolved. No staining was achieved with $\mathrm{CD} 20^{+}, \mathrm{CD} 21^{+}$, or any $\operatorname{IgG}(\mathrm{H}+\mathrm{L})$ antibodies. Anti-

204 human CD79 $\alpha_{c y}^{+}$(HM57, Dako) monoclonal antibody at 1:100 successfully stained lymph node

205 germinal centers with no background staining in equine brain (Fig. 1C, D).

206 Multiple macrophage-targeting antibodies were investigated. RAM 11 (Dako), AM-3K

207 (TransGenic Inc., Kobe, Japan), and $\mathrm{CD}^{+}$(KP1, Leica) antibodies had no reactivity with

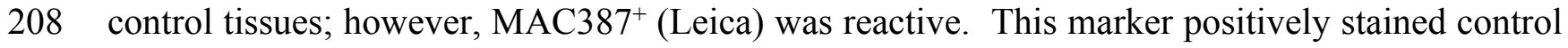

209 hepatic and thymic macrophages (Fig. 2A) with limited staining noted in lymph node sections.

210 Based on cell morphology, polymorphonuclear and mononuclear cells also stained positively due

211 to lack macrophage-specificity of the antibody. No reactivity was noted in normal equine brain.

212 The $\mathrm{MAC} 387^{+}$cell population was distinct from the distribution of $\mathrm{CD}^{+}$lymphocytes in brain

213 sections with inflammation due to WNV infection (Fig. 2B). Additionally, this macrophage 
214 antibody had little to no cross reactivity with brain microglia since few MAC387 ${ }^{+}$cells were

215 visualized within glial nodules of $\mathrm{WNV}^{+}$brain.

216 To characterize reactive gliosis, antibodies against both microglial and astrocytic markers were

217 tested. In non-infected brain tissue, Iba- $1^{+}$antibody stained scattered resident microglia with low

218 intensity, yet microglial processes were visualized (Fig. 2C). Staining intensity was higher in

219 WNV- infected brains (Fig. 2D). Astrocyte populations were identified with antibody against an

220 intermediate filament, glial fibrillary acid protein (GFAP), specific to astrocytes in CNS tissues.

221 This antibody reacted strongly with astrocytes in both normal and infected brains with distinct

222 astrocytic processes notable. $\mathrm{GFAP}^{+}$astrocytes were distributed within the brain parenchyma, at

223 the glia limitans, along brain vasculature, and in areas of gliosis of $\mathrm{WNV}^{+}$brains (Fig. 3).

224 Three antibodies that target neurofilament heavy-chain proteins (NF-H) of neuronal axons 225 successfully stained equine brain tissue. Swine derived, NAP4 (EnCor Biotechnology Inc.,

226 Gainesville, FL) antibody, was superior and stained neurons in both normal (Fig. 4) and infected

227 brains. Mouse monoclonal Neu-N antibody (A60, Millipore, Billerica, Massachusetts, USA),

228 which targets neuronal perikaryon, was also tested but without successful reactivity in equine 229 tissue.

230 Successful manual IHC protocols for these antibodies in equine neural tissue were identified

231 (Table 2). It should be noted that overnight, refrigeration with $\mathrm{CD}^{+}, \mathrm{CD}^{+}, \mathrm{MAC}^{+} 87^{+}$,

$232 \mathrm{GFAP}^{+}$, and $\mathrm{Iba}_{-1}^{+}$primary antibodies will successfully stain tissues and may provide flexibility

233 in laboratory scheduling if single-day protocol completion is not possible. 


\section{Discussion}

235 Formalin-fixed, paraffin embedded tissues are commonly archived for histological examination.

236 Formalin fixation and paraffin embedding samples retains tissue architecture and deactivates any

237 potential infectious agents (Cantile et al., 2001, Ritchey et al., 2006, and van Marle et al., 2007);

238 however, this process can block or destroy sensitive epitopes (Beckstead, 1994, Mérant et al., 239 2003, Terio et al., 2003, and Ibrahim et al., 2007). Despite reported reversal of these treatments,

240 the tested equine antigen derived $\mathrm{CD}^{+}$and $\mathrm{CD}^{+} \mathrm{T}$ cell were not detectable in FFPE. This

241 result has been described in other species (Beckstead, 1994, Bilzer et al., 1995, Zeng et al.,

242 1996, Gutierrez et al., 1999, and Härtig et al., 2009). Anti-CD4+ (mAb HB61A, VMRD) and

$243 \mathrm{CD}^{+}$(mAb HT14A, VMRD) monoclonal antibodies, however, were reactive to fresh, frozen

244 equine lymph node and infectious CNS tissue. Archiving tissues in both FFPE and fresh, frozen

245 tissue formats is recommended when investigating epitopes that may be affected by fixation.

246 After successful staining of control tissues, normal and pathologic brain tissue samples were then

247 tested alongside positive and negative tissue controls. Pathologic tissue samples included WNV-

248 infected brain, which contains reactive gliosis and perivascular cuffing of inflammatory cells

249 (Cantile et al., 2001, Ibrahim et al., 2007, van Marle et al., 2007, and Schnabel et al., 2013). S.

250 neurona infected tissues were also used, which contained focal nonsuppurative inflammation,

251 mononuclear perivascular cuffing, and the occurrence giants cells and eosinophils (Boy et al.,

2521990 and Dubey et al., 2001). Following this workflow of tissue testing aided in the

253 identification of successful antibody reactivity.

254 Several hurdles must be overcome to optimize the interaction of antibodies with their intended

255 targets. Aldehyde cross-links that bind tissue proteins during formalin fixation process must be

256 removed by HIER or proteolytic epitope retrieval to allow epitopes to resume a more natural 
257 confirmation and increase antibody-binding capacity (Shi et al., 1991, Ferrier et al., 1998, and

258 Krenacs et al., 2010). Peroxidases that naturally occur within tissues must be neutralized with

$259 \mathrm{H}_{2} \mathrm{O}_{2}$ in order to prevent non-specific staining during the application of peroxidase-based

260 substrate kits (Wendelboe and Bisgaard, 2013). Endogenous proteins may non-specifically

261 interact with antibodies and cause background staining that masks target antigen signal

262 (Daneshtalab et al., 2010 and Buchwalow et al., 2011). These unwanted binding sites must be

263 blocked. In this study a variety of reagents and methods were tested for each individual manual

264 IHC protocol. A base set of reliable solutions and techniques for testing antibodies was

265 identified in this study. These included $3 \% \mathrm{H}_{2} \mathrm{O}_{2}$, low $\mathrm{pH}$, citrate based HIER reagents in a

266 double-boiler, 5\% Immunopure ${ }^{\circledR}$ Goat Serum in PBS, Leica’s IHC Diluent, antibody incubation

267 for one hour at $37^{\circ} \mathrm{C}$, and the Novolink ${ }^{\mathrm{TM}}$ Polymer Detection System. However, with meticulous

268 tailoring of each antibody protocol, our results contained a variety of reagents that were

269 ultimately selected for each staining procedure.

270 Identification of equine-reactive antibodies can be challenging due to limited knowledge of

271 commercial antibodies' reactivity with veterinary tissues and lack of development of multiple

272 species-specific reagents. Evaluation of cross-species reactivity of commercially available

273 antibodies, particularly CD antigens, has been largely performed in equine tissues prepared for

274 whole-cell analysis like flow-cytometry (Johne et al., 1997, Mérant et al., 2003, Terio et al.,

275 2003, Kunisch et al., 2004, and Ibrahim et al., 2007) or on fresh or frozen specimens (Bilzer et

276 al., 1995, Zeng et al., 1996, Lemos et al., 2008, and Härtig et al., 2009). Large screenings of

277 non-equine derived antibodies have often resulted in limited identification of equine reactive

278 reagents (Ibrahim et al., 2007, Schnabel et al., 2013, and Szabo and Gulya, 2013). Of the 26

279 antibodies in this study, six antibodies successfully reacted with FFPE equine tissues. All six 
280 antibodies were derived from non-equine antigens. Their reactivity to equine tissue is likely due

281 to conserved epitope targets and the intracellular location of the antigen peptides (Jones et al.,

2821993 and Ahmed et al., 2007). If an antigen's peptide sequence is highly conserved across

283 multiple species, the production of antibodies from the immunized host may be inhibited due to

284 immune tolerance. However, because these antigens have intracellular origins, the host (i.e.

285 rabbit or mouse) is more likely to elicit an immune response upon antigen exposure. In this way,

286 these antibodies against human or swine antigen may successfully be produced and react with

287 equine or other species' tissues.

288 Commercial macrophage antibodies are non-specific to macrophages and often cross react with 289 monocytes, granulocytes, dendritic cells, and fibroblasts (Johne et al., 1997, Kunisch et al., 290 2004, Shaw et al., 2005, and Sellner et al., 2014). Multiple macrophage-directed antibodies with

291 different target antigens were tested so that a distinction could be made between tissue 292 macrophage populations and cells that may cross-react with those antibodies. RAM11 (Dako) 293 recognizes an uncharacterized, cytoplasmic antigen specific to rabbit macrophages. AM-3K 294 (TransGenic) anti-macrophage antibody raised against human alveolar macrophage antigen 295 recognizes cytoplasmic membrane epitopes. Anti-CD68 ${ }^{+}$(KP1, Leica) recognizes primarily 296 lysosomal membrane proteins of macrophages, secondarily macrophage membranes, and is 297 found on monocytes, neutrophils, basophils, and large lymphocytes. None of these three 298 antibodies were successfully reactive in FFPE brain or lymphoid tissues. Although frequently 299 used as a macrophage-characterizing marker, MAC $387^{+}$(Leica) recognizes cytoplasmic, human 300 leukocyte antigen, L1 protein found on neutrophils, monocytes, and certain reactive 301 macrophages. Only MAC $387^{+}$antibody was reactive with FFPE equine tissues, so the positively 302 stained population must be considered as a mix of both macrophages and neutrophils. This cell 
303 population had a distinct distribution in serial sections of WNV-infected brain each

304 immunolabeled for $\mathrm{MAC}_{387^{+}}, \mathrm{CD}^{+} \mathrm{T}$ lymphocytes, and microglia. In S. neurona infected

305 equine tissues, where multi-nucleated giant cells are observed, $\mathrm{MAC}_{38} 7^{+}$antibody did not react

306 with these cells even though there was reaction with single cells within each lesion.

307 Microglia, which are of a monocytic lineage, were identified with anti-Iba-1-antibody (Wako).

308 This antibody recognizes an intracellular, calcium binding protein basally expressed by both

309 microglia and macrophages, and upregulated in microglia following injury. Cell morphology,

310 specifically microglial processes, may be used to manually separate microglia and macrophage

311 populations. A limited number of equine studies have investigated microglial activation using

312 major histocompatibility complex (MHC) markers (Mullen et al., 1992 and Lemos et al., 2008).

313 MHC predominantly targets activated microglia populations, whereas anti-Iba- $1^{+}$antibody will

314 stain microglia in both their resting and activated form (Szabo and Gulya, 2013). Additionally,

315 using MHC as a marker for microglial cells in an inflammatory disease would also identify all

316 peripheral and CNS cells that have MHC upregulated due to this biological process.

317 Characterization of the total, both resting and activated, microglia population is therefore

318 improved with the use of Iba- $1^{+}$antibody (Ahmed et al., 2007).

319 Regarding detection of neurons, it must be recognized that NF-H proteins are concentrated 320 within axons and are weakly present within cell bodies. Changes in staining intensity within cell 321 bodies and dendrites with NF-H antibodies, such as NAP4 that targets phosphorylated NF-H

322 proteins, are useful for identifying neuropathology (Shaw et al., 2005 and Sellner et al., 2014).

323 For quantification of neuronal populations, an antibody specific to neuronal nuclei should be

324 used. Neu-N antibodies, which target DNA-binding proteins of neural nuclei, are typically used

325 for the staining and counting of neuron perikaryons (Mullen et al., 1992). 
326 This study successfully identified a collection of protocols for the characterization of cell

327 populations in the histopathology of encephalitic diseases in equine CNS tissues. This suite

328 included IHC staining of $\mathrm{CD}^{+} \mathrm{T}$ lymphocytes, CD79 $\mathrm{acy}^{+} \mathrm{B}$ lymphocytes, MAC387

329 macrophages and neutrophils, Iba- $1^{+}$microglia, GFAP ${ }^{+}$astrocytes, and $\mathrm{NF}-\mathrm{H}^{+}$neurons in FFPE

330 tissues. The suite was expanded with the inclusion of $\mathrm{CD} 4^{+}$and $\mathrm{CD} 8^{+} \mathrm{T}$ lymphocytes in fresh,

331 frozen tissue sections. Useful application of these antibodies was supported with the

332 characterization of neuropathology in diseased horses with clinical and experimental West Nile

333 encephalitis, clinical equine protozoal myeloencephalitis, and, preliminarily, clinical Eastern

334 equine encephalitis. Western blot analysis utilizing these antibodies should next be performed to

335 support the specificity of their reactivity in the horse.

\section{Acknowledgements}

337 We would like to thank Dr. Gerry Shaw and Dr. W. Jake Streit for their consultation and loan of 338 antibodies. 
341 Fig 1 - For the detection of lymphocytes, (A, C) equine lymph node cortex and (B, D) WNV

342 infected equine brain incubated with $(\mathrm{A}, \mathrm{B}) \mathrm{CD}^{+} \mathrm{T}$ lymphocyte primary antibody (pAb A0452,

343 Dako) for 60 minutes at $37^{\circ} \mathrm{C}$ and detected by Vectastain ${ }^{\circledR} \mathrm{ABC}$ Kit, or incubated with (C, D)

$344 \mathrm{CD} \mathrm{acy}^{+} \mathrm{B}$ lymphocyte primary antibody (mAb HM57, Dako) for 90 minutes at $37^{\circ} \mathrm{C}$ and

345 detected by Novolink ${ }^{\mathrm{TM}}$ Polymer Detection System. Vector NovaRED Peroxidase Substrate

346 chromogen and hematoxylin couterstain. Bar, $50 \mu \mathrm{m}$.

347 Fig 2 - For the detection of macrophage/microglial lineage cells, (A) equine thymus and (B)

348 WNV infected equine brain were incubated with MAC $387^{+}$primary antibody (mAb MAC387,

349 Leica) for 60 minutes at $37^{\circ} \mathrm{C}$ and detected by Vectastain ${ }^{\circledR} \mathrm{ABC}$ Kit. Additionally, (C) normal

350 (arrows) and (D) WNV infected horse brain were incubated with microglia/macrophage primary

351 antibody (pAb Iba-1, Wako) for 60 minutes at $37^{\circ} \mathrm{C}$ and detected by Novolink ${ }^{\mathrm{TM}}$ Polymer

352 Detection System. Vector NovaRED Peroxidase Substrate chromogen and hematoxylin 353 couterstain. Bar, $50 \mu \mathrm{m}$.

354 Fig 3- $\mathrm{GFAP}^{+}$astrocytes in WNV infected equine brain (A) near blood vessels and (B) at the 355 glial limitans. Tissues were incubated with GFAP+ astrocyte primary antibody (mAb 5C10, 356 EnCor Biotechnology) for 60 minutes at $37^{\circ} \mathrm{C}$ and detected by Vectastain ${ }^{\circledR} \mathrm{ABC}$ Kit. Vector 357 NovaRED Peroxidase Substrate chromogen and hematoxylin couterstain. Bar, $50 \mu \mathrm{m}$.

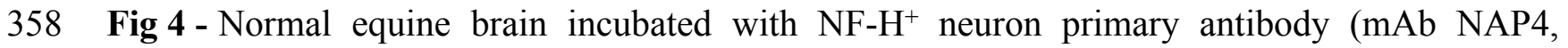
359 EnCor Biotechnology), for 60 minutes at $37^{\circ} \mathrm{C}$ and detected by Novolink ${ }^{\mathrm{TM}}$ Polymer Detection 360 System. Vector NovaRED Peroxidase Substrate chromogen and hematoxylin couterstain. Bar, 50 $361 \mu \mathrm{m}$. 


\section{References}

364 Ahmed, Z., Shaw, G., Sharma, V.P., Yang, C., McGowan, E., Dickson, D.W. (2007) Actin-

365 binding proteins coronin-1a and IBA-1 are effective microglial markers for

366 immunohistochemistry. The journal of histochemistry and cytochemistry : official journal of the

367 Histochemistry Society. 55(7), 687-700.

368 Beckstead, J.H. (1994) A simple technique for preservation of fixation-sensitive antigens in

369 paraffin-embedded tissues. The journal of histochemistry and cytochemistry : official journal of

370 the Histochemistry Society. 42(8), 1127-1134.

371 Bilzer, T., Planz, O., Lipkin, W.I., Stitz, L. (1995) Presence of CD4+ and CD8+ T cells and

372 expression of MHC class I and MHC class II antigen in horses with Borna disease virus-induced

373 encephalitis. Brain pathology (Zurich, Switzerland). 5(3), 223-230.

374 Bourgeois, M.A., Denslow, N.D., Seino, K.S., Barber, D.S., Long, M.T. (2011) Gene expression

375 analysis in the thalamus and cerebrum of horses experimentally infected with West Nile virus.

376 PloS one. 6(10), e24371.

377 Boy, M.G., Galligan, D.T., Divers, T.J. (1990) Protozoal encephalomyelitis in horses: 82 cases

378 (1972-1986). Journal of the American Veterinary Medical Association. 196(4), 632-634.

379 Cantile, C., Del Piero, F., Di Guardo, G., Arispici, M. (2001) Pathologic and

380 Immunohistochemical Findings in Naturally Occurring West Nile Virus Infection in Horses.

381 Veterinary Pathology. 38(4), 414-431.

382 DAKO (2009) Chapter 8 Demasking of Antigens In: Immunohistochemical Staining Methods.

383 Fifth. G. L. Kumar \& L. Rudbeck, eds. Dako North America. 
384 Dubey, J.P., Lindsay, D.S., Saville, W.J., Reed, S.M., Granstrom, D.E., Speer, C.A. (2001) A

385 review of Sarcocystis neurona and equine protozoal myeloencephalitis (EPM). Veterinary 386 parasitology. 95(2-4), 89-131.

387 Grosche, A., Freeman, D.E., Morton, A.J., Polyak, M.M.R., Matyjaszek, S.A. (2012) Effects of 388 ischemia and reperfusion on production of nitrotyrosine, activation of eosinophils, and apoptosis 389 in the large colonic mucosa of horses. American journal of veterinary research. 73(1), 53-61.

390 Gutierrez, M., Forster, F.I., McConnell, S.A., Cassidy, J.P., Pollock, J.M., Bryson, D.G. (1999)

391 The detection of $\mathrm{CD} 2+, \mathrm{CD} 4+, \mathrm{CD} 8+$, and $\mathrm{WC} 1+\mathrm{T}$ lymphocytes, $\mathrm{B}$ cells and macrophages in 392 fixed and paraffin embedded bovine tissue using a range of antigen recovery and signal 393 amplification techniques. Veterinary immunology and immunopathology. 71(3-4), 321-334.

394 Härtig, W., Reichenbach, A., Voigt, C., Boltze, J., Bulavina, L., Schuhmann, M.U., Seeger, J., 395 Schusser, G.F., Freytag, C., Grosche, J. (2009) Triple fluorescence labelling of neuronal, glial 396 and vascular markers revealing pathological alterations in various animal models. Journal of 397 chemical neuroanatomy. 37(2), 128-138.

398 Ibrahim, S., Saunders, K., Kydd, J.H., Lunn, D.P., Steinbach, F. (2007) Screening of anti-human 399 leukocyte monoclonal antibodies for reactivity with equine leukocytes. Veterinary immunology 400 and immunopathology. 119(1-2), 63-80.

401 Johne, B., Fagerhol, M.K., Lyberg, T., Prydz, H., Brandtzaeg, P., Naess-Andresen, C.F., Dale, I. 402 (1997) Functional and clinical aspects of the myelomonocyte protein calprotectin. Molecular 403 pathology : MP. 50(3), 113-123.

404 Jones, M., Cordell, J.L., Beyers, A.D., Tse, A.G., Mason, D.Y. (1993) Detection of T and B cells 
405 in many animal species using cross-reactive anti-peptide antibodies. Journal of immunology 406 (Baltimore, Md. : 1950). 150(12), 5429-5435.

407 Kunisch, E., Fuhrmann, R., Roth, A., Winter, R., Lungershausen, W., Kinne, R.W. (2004)

408 Macrophage specificity of three anti-CD68 monoclonal antibodies (KP1, EBM11, and PGM1)

409 widely used for immunohistochemistry and flow cytometry. Annals of the rheumatic diseases. $410 \quad 63(7), 774-784$.

411 Lemos, K.R., Marques, L.C., Aquino, L.P.C.T., Alessi, A.C., Zacarias, R.Z. (2008) Astrocytic 412 and microglial response and histopathological changes in the brain of horses with experimental 413 chronic Trypanosoma evansi infection. Revista do Instituto de Medicina Tropical de São Paulo. $414 \mathbf{5 0}(4), 243-249$.

415 Matyjaszek, S.A., Morton, A.J., Freeman, D.E., Grosche, A., Polyak, M.M.R., Kuck, H. (2009) 416 Effects of flunixin meglumine on recovery of colonic mucosa from ischemia in horses. American 417 journal of veterinary research. 70(2), 236-246.

418 Mérant, C., Bonnefont, C., Desbos, A., Greenland, T., Cadoré, J.-L., Monier, J.-C. (2003) Cross419 species reactivity of seven monoclonal antibodies with equine lymphocytes by flow cytometry. 420 Veterinary research. 34(6), 791-801.

421 Mullen, R.J., Buck, C.R., Smith, A.M. (1992) NeuN, a neuronal specific nuclear protein in 422 vertebrates. Development (Cambridge, England). 116(1), 201-211.

423 Porter, M.B., Long, M.T., Getman, L.M., Giguère, S., MacKay, R.J., Lester, G.D., Alleman, 424 A.R., Wamsley, H.L., Franklin, R.P., Jacks, S., Buergelt, C.D., Detrisac, C.J. (2003) West Nile 425 virus encephalomyelitis in horses: 46 cases (2001). Journal of the American Veterinary Medical 
426

Association. 222(9), 1241-1247.

427 Ramos-Vara, J.A. (2005) Technical aspects of immunohistochemistry. Veterinary Pathology. $428 \quad 42(4), 405-426$.

429 Ritchey, J.W., Black, D.H., Rogers, K.M., Eberle, R. (2006) In vivo experimentation with simian 430 herpesviruses: assessment of biosafety and molecular contamination. Journal of the American 431 Association for Laboratory Animal Science : JAALAS. 45(2), 7-12.

432 Rushton, J.O., Lecollinet, S., Hubálek, Z., Svobodová, P., Lussy, H., Nowotny, N. (2013) Tick433 borne encephalitis virus in horses, Austria, 2011. Emerging infectious diseases. 19(4), 635-637.

434 Schnabel, C.L., Wagner, S., Wagner, B., Durán, M.C., Babasyan, S., Nolte, I., Pfarrer, C., Feige, 435 K., Murua Escobar, H., Cavalleri, J.-M.V. (2013) Evaluation of the reactivity of commercially 436 available monoclonal antibodies with equine cytokines. Veterinary immunology and 437 immunopathology. 156(1-2), 1-19.

Seino, K.K., Long, M.T., Gibbs, E.P.J., Bowen, R.A., Beachboard, S.E., Humphrey, P.P., Dixon, 439

Sellner, J., Davies, N.W., Howard, R.S., Petzold, A. (2014) Neurofilament heavy chain as a 443

444 neurology : the official journal of the European Federation of Neurological Societies. 21(6), $445 \quad 845-850$. 
446 Shaw, G., Yang, C., Ellis, R., Anderson, K., Parker Mickle, J., Scheff, S., Pike, B., Anderson,

447 D.K., Howland, D.R. (2005) Hyperphosphorylated neurofilament NF-H is a serum biomarker of 448 axonal injury. Biochemical and biophysical research communications. 336(4), 1268-1277.

449 Szabo, M., Gulya, K. (2013) Development of the microglial phenotype in culture. Neuroscience. $450 \quad 241,280-295$.

451 Terio, K.A., Stalis, I.H., Allen, J.L., Stott, J.L., Worley, M.B. (2003) Coccidioidomycosis in 452 Przewalski's horses (Equus przewalskii). Journal of zoo and wildlife medicine : official 453 publication of the American Association of Zoo Veterinarians. 34(4), 339-345.

454 van Marle, G.G., Antony, J.J., Ostermann, H.H., Dunham, C.C., Hunt, T.T., Halliday, W.W., 455 Maingat, F.F., Urbanowski, M.D.M., Hobman, T.T., Peeling, J.J., Power, C.C. (2007) West Nile 456 virus-induced neuroinflammation: glial infection and capsid protein-mediated neurovirulence. 457 Journal of Virology. 81(20), 10933-10949.

458 Yu, G.-Y., Wiley, M.R., Kugelman, J.R., Ladner, J.T., Beitzel, B.F., Eccleston, L.T., Morazzani, 459 E.M., Glass, P.J., Palacios, G.F. (2015) Complete coding sequences of eastern equine 460 encephalitis virus and venezuelan equine encephalitis virus strains isolated from human cases. 461 Genome announcements. 3(2).

462 Zeng, L., Takeya, M., Ling, X., Nagasaki, A., Takahashi, K. (1996) Interspecies reactivities of 463 anti-human macrophage monoclonal antibodies to various animal species. The journal of 464 histochemistry and cytochemistry : official journal of the Histochemistry Society. 44(8), 845465853. 


\section{Table $\mathbf{1}$ (on next page)}

Antibodies tested for immunohistochemical reactivity in equine tissues. 
1 Table 1. Antibodies tested for immunohistochemical reactivity in equine tissues.

\begin{tabular}{|c|c|c|c|c|c|c|}
\hline Antibody & $\begin{array}{l}\text { Antigen } \\
\text { Species }\end{array}$ & $\begin{array}{l}\text { Host } \\
\text { Species }\end{array}$ & Isotype & Name or Clone & Protein Target & Source \\
\hline CD3 & Human & Mouse & IgG1 & F7.2.38 & $\begin{array}{l}\text { Thymocytes, T lymphocytes, } \\
\text { natural killer cells }\end{array}$ & Dako \\
\hline CD3 & Human & Rabbit & - & A0452 & T lymphocytes & Dako \\
\hline CD4 & Equine & Mouse & IgG1 & CVS4 & T helpers & $\mathrm{AbD}$ \\
\hline CD4 & Human & Mouse & IgG1 & 4B12 & $\begin{array}{l}\text { Thymocytes, } \mathrm{T} \text { helpers, mature } \\
\text { peripheral } \mathrm{T} \text { cells, TReg or } \\
\text { cytotoxic T cell subsets }\end{array}$ & Dako \\
\hline CD4 & Human & Mouse & $\operatorname{IgG} 1$ & $1 \mathrm{~F} 6$ & $\mathrm{~T}$ helpers & Leica \\
\hline CD4 & Equine & Mouse & IgG1 & HB61A & Thymocytes, T helpers & VMRD \\
\hline CD8 & Equine & Mouse & IgG1 & CVS8 & Cytotoxic T lymphocytes & $\mathrm{AbD}$ \\
\hline CD8 & Equine & Mouse & IgG1 & HT14A & $\begin{array}{l}\text { Thymocytes, Cytotoxic T } \\
\text { lymphocytes }\end{array}$ & VMRD \\
\hline CD5 & Equine/Bovine & Mouse & $\operatorname{IgG} 2 \mathrm{~A}$ & B29A & B lymphocytes only, in horses & VMRD \\
\hline $\mathrm{CD} 20$ & Human & Mouse & $\operatorname{IgG} 1$ & MJ1 & B lymphocytes & Leica \\
\hline CD21 & Human & Mouse & IgG1 & $\mathrm{Bu} 33$ & B lymphocytes & $\mathrm{AbD}$ \\
\hline CD21 & Human & Mouse & IgG1 & $1 \mathrm{~F} 8$ & B lymphocytes & Dako \\
\hline CD79 $\alpha$ cy & Human & Mouse & IgG1 & HM57 & B lymphocytes & Dako \\
\hline $\operatorname{IgG}(\mathrm{H} \& \mathrm{~L})$ & Equine & Goat & $\mathrm{IgG}$ & A70-106 & B lymphocytes & Bethyl \\
\hline $\operatorname{IgG}(\mathrm{H} \& \mathrm{~L})$ & Equine & Rabbit & IgG & A70-118 & B lymphocytes & Bethyl \\
\hline $\operatorname{IgG}(\mathrm{H} \& \mathrm{~L})$ & Goat & Rabbit & IgG & A50-100 & B lymphocytes & Zymed \\
\hline Macrophage & Rabbit & Mouse & IgG1 & RAM11 & Macrophages & Dako \\
\hline Macrophage & Human & Mouse & $\operatorname{IgG} 1$ & MAC387 & Macrophages & Leica \\
\hline Macrophage & Human & Mouse & IgG1 & AM-3K & Macrophages & TransGenic \\
\hline CD68 & Human & Mouse & IgG1 & CD68-KP1 & Macrophages & Leica \\
\hline $\mathrm{NF}-\mathrm{H}$ & Bovine & Mouse & $\operatorname{IgG} 2 b$ & $9 \mathrm{~B} 12$ & Neurofilament-Heavy chain & $\begin{array}{l}\text { EnCor- } \\
\text { Biotechnology }\end{array}$ \\
\hline NF-H & Bovine & Mouse & IgG1 & AH1 & Neurofilament-Heavy chain & $\begin{array}{l}\text { EnCor- } \\
\text { Biotechnology }\end{array}$ \\
\hline $\mathrm{NF}-\mathrm{H}$ & Swine & Mouse & IgG1 & NAP4 & Neurofilament-Heavy chain & $\begin{array}{l}\text { EnCor- } \\
\text { Biotechnology }\end{array}$ \\
\hline GFAP & Swine & Mouse & IgG1 & $5 \mathrm{C} 10$ & $\begin{array}{l}\text { Astrocytes, Satellite cells, Schwann } \\
\text { cells }\end{array}$ & $\begin{array}{l}\text { EnCor- } \\
\text { Biotechnology }\end{array}$ \\
\hline Microglia & Human & Rabbit & - & Iba-1 & Microglia, macrophages & Wako \\
\hline Neu-N & Mouse & Mouse & IgG1 & A60 & Neurons & Millipore \\
\hline
\end{tabular}


Table 2 (on next page)

Selected protocols for immunohistochemical visualization of resident and infiltrative cells in normal and WNV-diseased equine CNS tissues. 
1 Table 2. Selected protocols for immunohistochemical visualization of resident and 2 infiltrative cells in normal and WNV-diseased equine CNS tissues.

\begin{tabular}{|c|c|c|c|c|c|c|c|c|}
\hline Antibody & $\begin{array}{l}\text { ID/ } \\
\text { Clone }\end{array}$ & $\begin{array}{l}\text { Tissue } \\
\text { format }\end{array}$ & $\begin{array}{c}\text { Peroxidase } \\
\text { Blocker }\end{array}$ & $\begin{array}{l}\text { Antigen } \\
\text { Retrieval }\end{array}$ & Blocker & Dilution & Incubation & $\begin{array}{l}\text { Commercial } \\
\text { Secondary Kit }\end{array}$ \\
\hline CD3 & A0452 & FFPE & $3 \% \mathrm{H}_{2} \mathrm{O}_{2}$ & $\begin{array}{l}\text { Target } \\
\text { Retrieval } \\
\text { Solution } \\
\text { pH6 } 6^{5}\end{array}$ & $\begin{array}{l}10 \% \\
\text { Normal } \\
\text { Goat } \\
\text { Serum }^{1}\end{array}$ & $1: 100$ & $\begin{array}{l}60 \text { min at } \\
37^{\circ} \mathrm{C}\end{array}$ & $\begin{array}{l}\text { Vectastain }{ }^{\circledR A B C} \\
\text { Kit - Rabbit }{ }^{3}\end{array}$ \\
\hline CD4 & HB61A & FFT & $0.3 \% \mathrm{H}_{2} \mathrm{O}_{2}$ & None & $\begin{array}{l}\text { Protein } \\
\text { Block }^{2}\end{array}$ & $1: 800$ & $\begin{array}{l}120 \text { min at } \\
23^{\circ} \mathrm{C}\end{array}$ & $\begin{array}{l}\text { Post Primary } \\
\text { Block \& Novolink } \\
\text { Polymer }^{2}\end{array}$ \\
\hline CD8 & HT14A & FFT & $0.3 \% \mathrm{H}_{2} \mathrm{O}_{2}$ & None & $\begin{array}{l}\text { Protein } \\
\text { Block }^{2}\end{array}$ & $1: 800$ & $\begin{array}{l}120 \text { min at } \\
23^{\circ} \mathrm{C}\end{array}$ & $\begin{array}{l}\text { Post Primary } \\
\text { Block \& Novolink } \\
\text { Polymer }^{2}\end{array}$ \\
\hline $\begin{array}{l}\mathrm{CD} 79 \alpha \mathrm{C} \\
\mathrm{Y}\end{array}$ & HM57 & FFPE & $3 \% \mathrm{H}_{2} \mathrm{O}_{2}$ & $\begin{array}{l}\text { Epitope } \\
\text { Retrieval } \\
\text { Solution } \\
\text { pH6 }{ }^{2}\end{array}$ & $\begin{array}{l}5 \% \\
\text { Immune } \\
\text { Pure Goat } \\
\text { Serum }^{4}\end{array}$ & $1: 100$ & $\begin{array}{l}90 \mathrm{~min} \\
37^{\circ} \mathrm{C}\end{array}$ & $\begin{array}{l}\text { Post Primary } \\
\text { Block \& Novolink } \\
\text { Polymer }^{2}\end{array}$ \\
\hline $\begin{array}{l}\text { Macroph } \\
\text { age }\end{array}$ & $\begin{array}{l}\text { MAC3 } \\
87\end{array}$ & FFPE & $3 \% \mathrm{H}_{2} \mathrm{O}_{2}$ & $\begin{array}{l}\text { Target } \\
\text { Retrieval } \\
\text { Solution } \\
\mathrm{pH}^{5} \\
\text { Or } \\
\text { Proteinase } \\
\mathrm{K}\end{array}$ & $\begin{array}{l}10 \% \\
\text { Normal } \\
\text { Goat } \\
\text { Serum }^{1}\end{array}$ & $1: 100$ & $\begin{array}{l}60 \mathrm{~min} \text { at } \\
37^{\circ} \mathrm{C}\end{array}$ & $\begin{array}{l}\text { Vectastain }{ }^{\circledR} A B C \\
\text { Kit }^{- \text {Mouse }^{3}}\end{array}$ \\
\hline NF-H & $\begin{array}{l}\text { NAP4, } \\
\text { AH1, } \\
9 B 12\end{array}$ & FFPE & $3 \% \mathrm{H}_{2} \mathrm{O}_{2}$ & $\begin{array}{l}\text { Epitope } \\
\text { Retrieval } \\
\text { Solution } \\
\text { pH6 }{ }^{2}\end{array}$ & $\begin{array}{l}\text { Protein } \\
\text { Block }^{2}\end{array}$ & $1: 1,000$ & $\begin{array}{l}60 \mathrm{~min} \text { at } \\
37^{\circ} \mathrm{C}\end{array}$ & $\begin{array}{l}\text { Post Primary } \\
\text { Block \& Novolink } \\
\text { Polymer }^{2}\end{array}$ \\
\hline GFAP & $5 \mathrm{C} 10$ & FFPE & $3 \% \mathrm{H}_{2} \mathrm{O}_{2}$ & $\begin{array}{l}\text { Target } \\
\text { Retrieval } \\
\text { Solution } \\
\text { pH6 }\end{array}$ & $\begin{array}{l}5 \% \\
\text { Immune } \\
\text { Pure Goat } \\
\text { Serum }^{4}\end{array}$ & $1: 8,000$ & $\begin{array}{l}60 \mathrm{~min} \text { at } \\
37^{\circ} \mathrm{C}\end{array}$ & $\begin{array}{l}\text { Vectastain }{ }^{\circledR} A B C \\
\text { Kit - Mouse }\end{array}$ \\
\hline Iba-1 & - & FFPE & $3 \% \mathrm{H}_{2} \mathrm{O}_{2}$ & None & $\begin{array}{l}\text { Protein } \\
\text { Block }^{2}\end{array}$ & $1: 500$ & $\begin{array}{l}60 \text { min at } \\
37^{\circ} \mathrm{C}\end{array}$ & $\begin{array}{l}\text { Post Primary } \\
\text { Block \& Novolink } \\
\text { Polymer }^{2}\end{array}$ \\
\hline
\end{tabular}

3 FFPE - Formalin-fixed, paraffin embedded; FFT - Fresh, frozen tissue

$4 \quad{ }^{1}$ Invitrogen ${ }^{\mathrm{TM}} \quad{ }^{2}$ Leica ${ }^{\circledR}$ - Novocastra ${ }^{\mathrm{TM}}$ Product Line ${ }^{3}$ Vector Labs ${ }^{\circledR} \quad{ }^{4}$ FischerScientific $^{\circledR} \quad{ }^{5} \mathrm{Dako}^{\circledR}$ 


\section{1}

$\mathrm{IHC}$ of $\mathrm{CD}^{+} \mathrm{T}$ lymphocytes and $\mathrm{CD} 79^{+} \mathrm{B}$ lymphocytes in euqine tissues.

Fig 1 - For the detection of lymphocytes, (A, C) equine lymph node cortex and (B, D) WNV infected equine brain incubated with (A, B) $\mathrm{CD}^{+} \mathrm{T}$ lymphocyte primary antibody (pAb A0452, Dako) for 60 minutes at $37^{\circ} \mathrm{C}$ and detected by Vectastain ${ }^{\oplus} \mathrm{ABC}$ Kit, or incubated with (C, D) $\mathrm{CD} 79 \alpha \mathrm{Cy}^{+} \mathrm{B}$ lymphocyte primary antibody (mAb HM57, Dako) for 90 minutes at $37^{\circ} \mathrm{C}$ and detected by Novolink ${ }^{\mathrm{Tm}}$ Polymer Detection System. Vector NovaRED Peroxidase Substrate chromogen and hematoxylin couterstain. Bar, $50 \mu \mathrm{m}$.

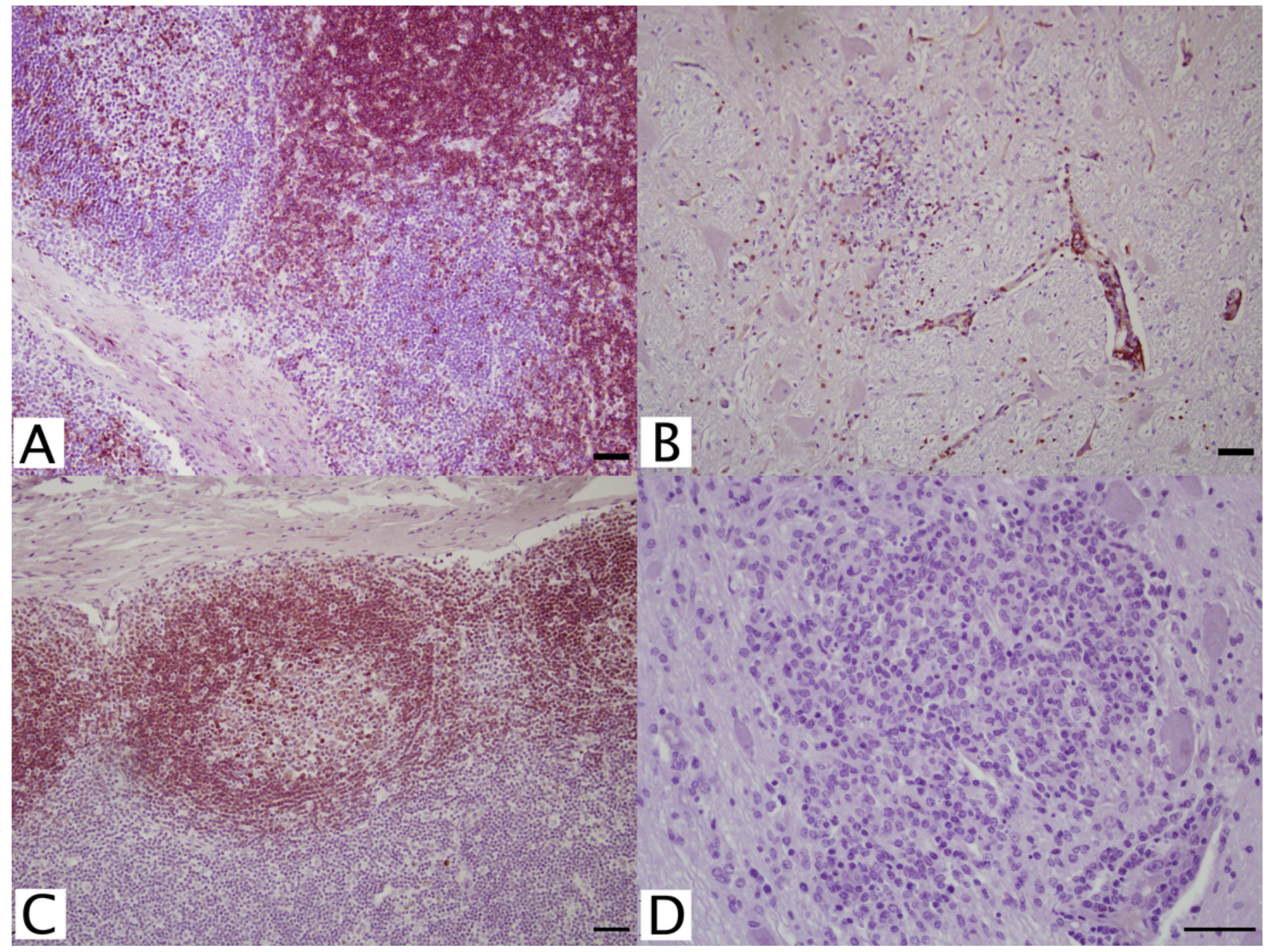




\section{2}

IHC of MAC $387^{+}$and $\mathrm{lba}-1^{+}$macrophages and microglia in equine tissues.

Fig 2 - For the detection of macrophage/microglial lineage cells, (A) equine thymus and (B) WNV infected equine brain were incubated with MAC387 ${ }^{+}$primary antibody (mAb MAC387, Leica) for 60 minutes at $37^{\circ} \mathrm{C}$ and detected by Vectastain ${ }^{\circledR} \mathrm{ABC}$ Kit. Additionally, (C) normal (arrows) and (D) WNV infected horse brain were incubated with microglia/macrophage primary antibody (pAb Iba-1, Wako) for 60 minutes at $37^{\circ} \mathrm{C}$ and detected by Novolink ${ }^{\mathrm{TM}}$ Polymer Detection System. Vector NovaRED Peroxidase Substrate chromogen and hematoxylin couterstain. Bar, $50 \mu \mathrm{m}$.

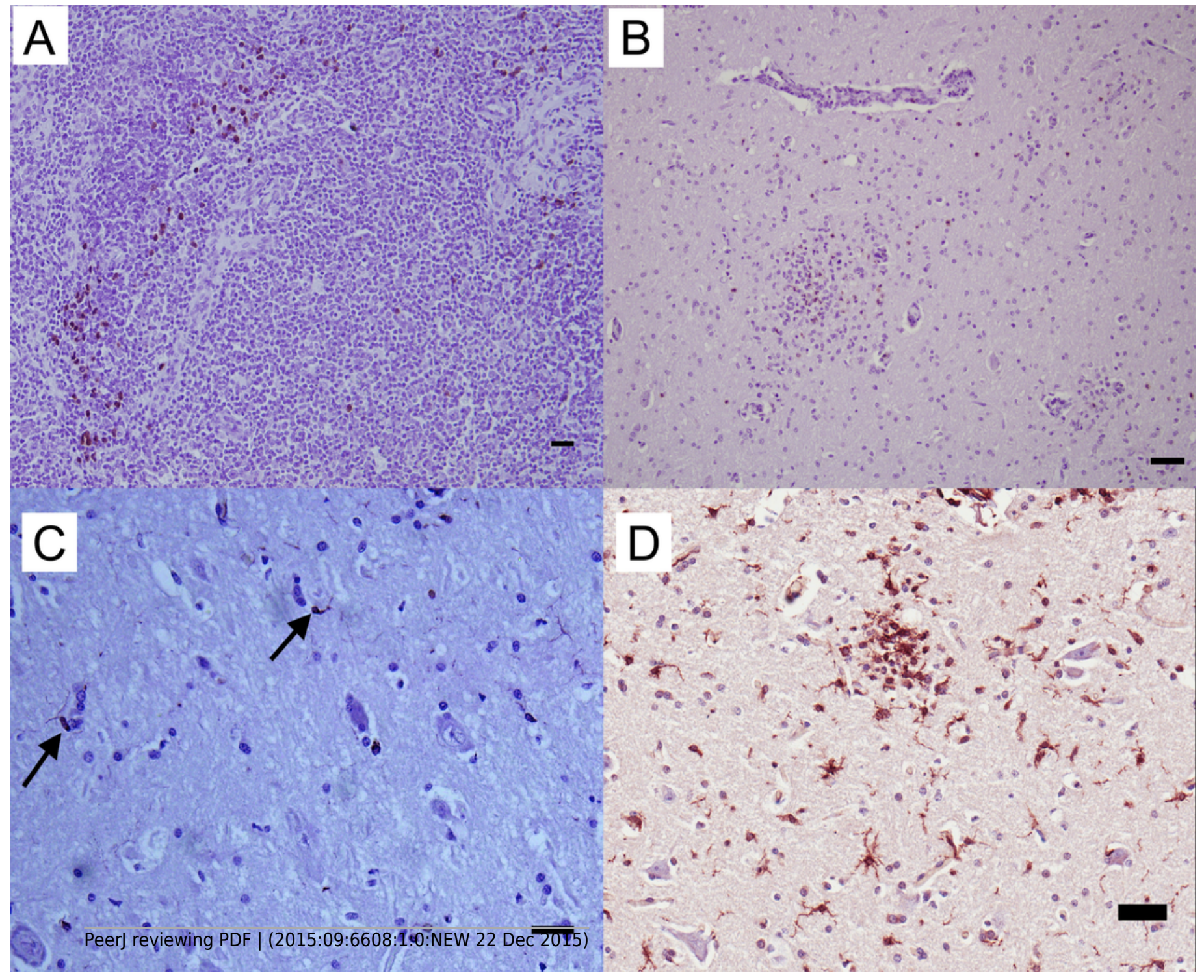




\section{3}

IHC of GFAP+ astrocytes in WNV infected equine brain.

Fig. 5. $G F A P^{+}$astrocytes in WNV infected equine brain (A) near blood vessels and (B) at the glial limitans. IHC. Bar, $50 \mu \mathrm{m}$.

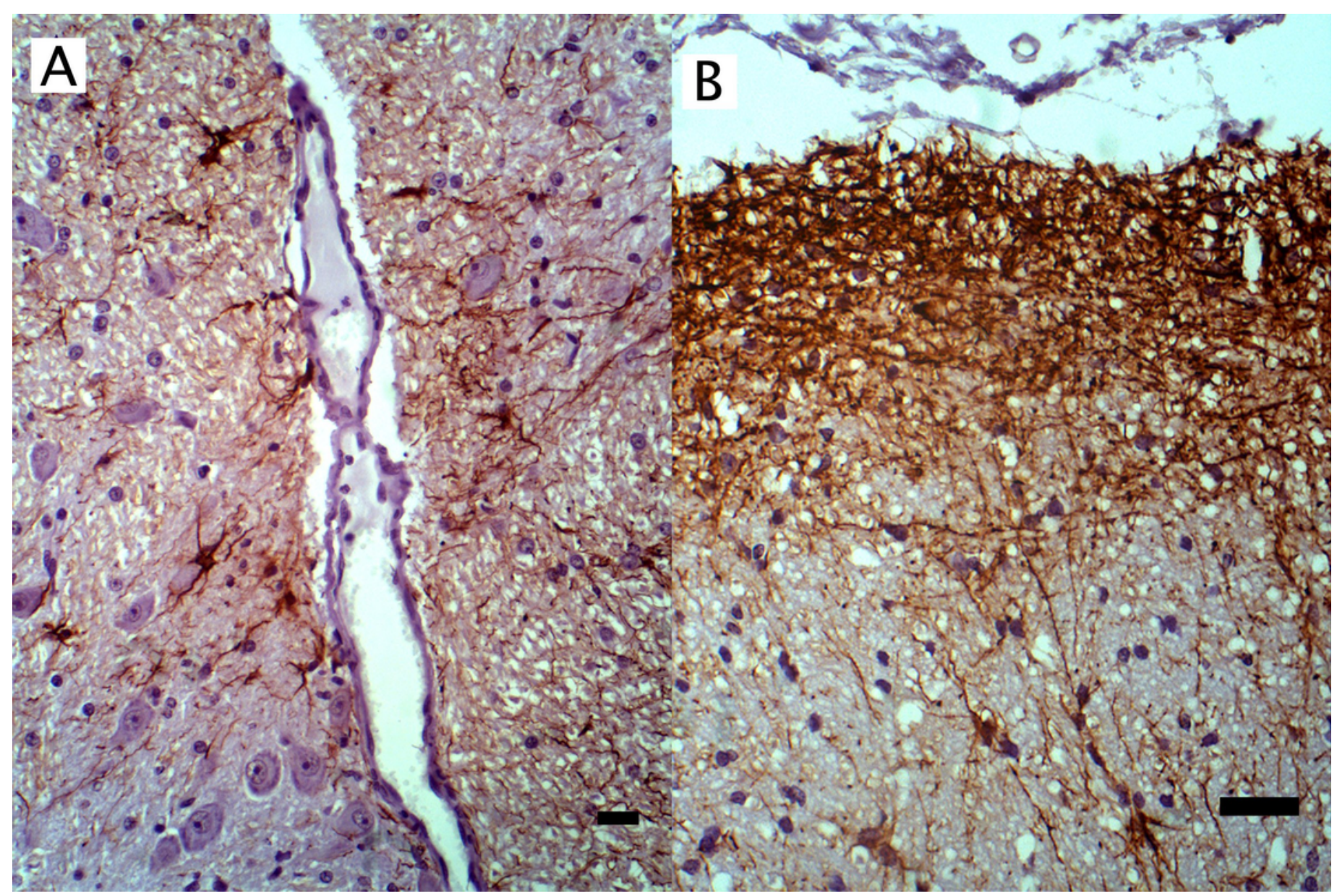


4

$\mathrm{IHC}$ of $\mathrm{NF}-\mathrm{H}^{+}$neurons in equine brain.

Fig 4 - Normal equine brain incubated with NF-H ${ }^{+}$neuron primary antibody (mAb NAP4, EnCor Biotechnology), for 60 minutes at $37^{\circ} \mathrm{C}$ and detected by Novolink ${ }^{\mathrm{TM}}$ Polymer Detection System. Vector NovaRED Peroxidase Substrate chromogen and hematoxylin couterstain. Bar, $50 \mu \mathrm{m}$.

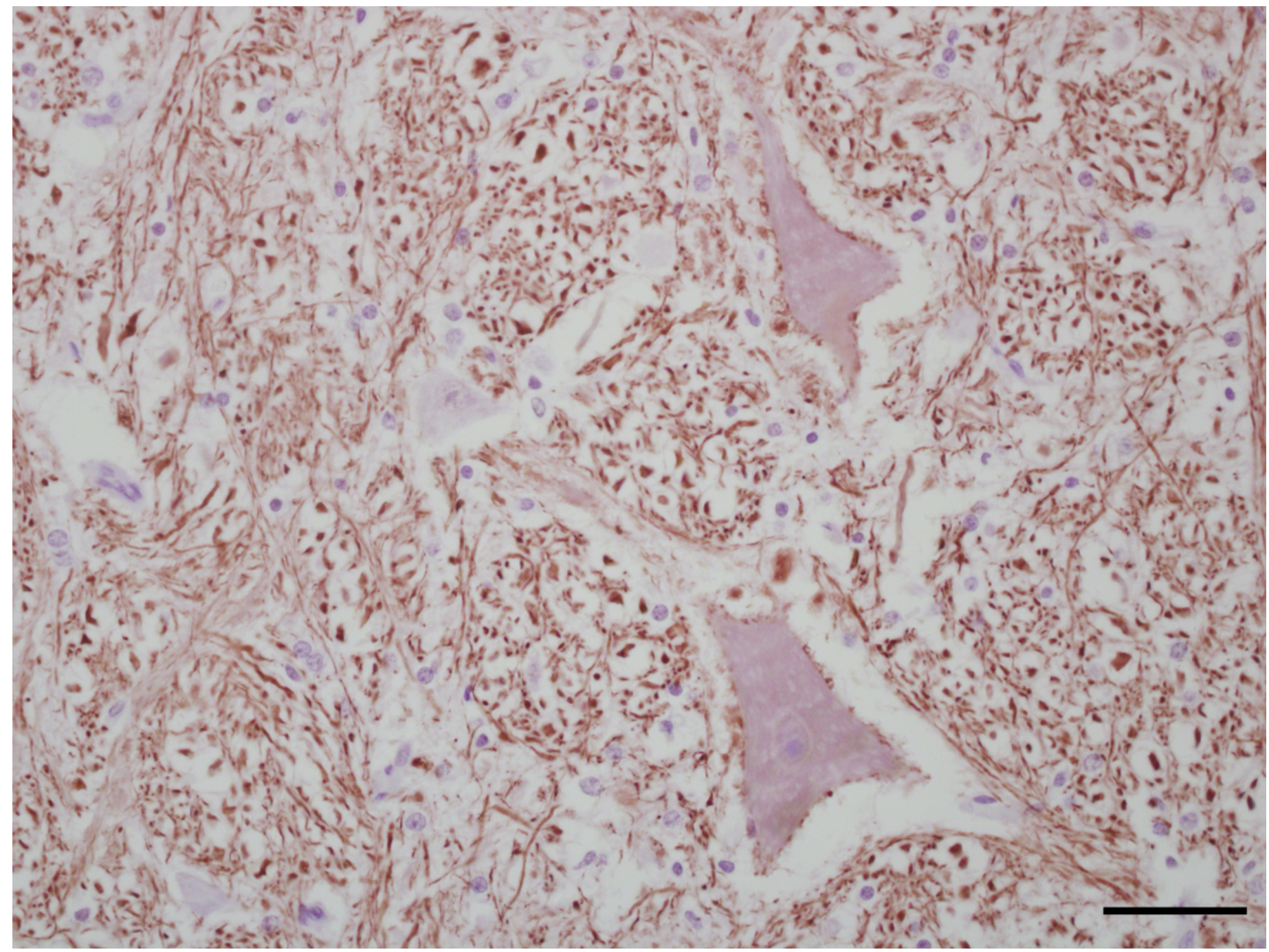

